\title{
Ewing Sarcoma/Peripheral Primitive Neuroectodermal Tumor of Bone
}

National Cancer Institute

\section{Source}

National Cancer Institute. Ewing Sarcoma/Peripheral Primitive Neuroectodermal Tumor

of Bone. NCI Thesaurus. Code C35871.

A spectrum of malignant tumors arising from the bone and characterized morphologically by the presence of small round cells. Ewing sarcoma and peripheral primitive neuroectodermal tumor represent the ends of a spectrum, with Ewing sarcoma lacking evidence of neural differentiation and the markers that characterize the peripheral primitive neuroectodermal tumor. Ewing sarcoma and peripheral primitive neuroectodermal tumor may share cytogenetic abnormalities, proto-oncogene expression, cell culture and immunohistochemical abnormalities. Pain and the presence of a mass are the most common clinical symptoms. 